WIELKIE TEMATY KULTURY W LITERATURACH SKOWIAŃSKICH

Slavica Wratislaviensia CLXVIII • Wrocław 2019•AUWr No 3875

DOI: $10.19195 / 0137-1150.168 .9$

Data przesłania artykułu: 1.10 .2017

Data akceptacji artykułu: 1.02.2018

\title{
HALYNA KHOMENKO
}

Харківський національний педагогічний університет імені Григорія Сковороди, Ukraina

\section{Микола Хвильовий: вибух мовчання в Театрі Смерті}

Схильний до варіацій і парадоксів наш час виявляє особливий інтерес до Театру Смерті, мультиаспектна ідентифікація якого супроводжується все-таки акцентом традиційного атрибуту смерті - мовчання. Розхитування усталених характеристик смерті, яка у своїй таємничості постає безповоротною, непровіщуваною, безмовною, що визначає навіть статус трупа, неспроможного бути співрозмовником живих, відповідати на їх звернення, приводить до визнання смертного мовчання за джерело мови й життя.

Прозора ономастика Театру Смерті дозволяє констатувати його реакцію на множину феноменів. Це насамперед окільний відхід від досвіду Театру Смерті Моріса Метерлінка, де Смерть засвідчує або свою присутність на сцені, або герої відчувають ії незриму присутність як неминучість Ананке, реагуючи на приреченість відчаєм німоти. Власне, тут і починається окреслена непростота: вибух мовчання - парадокс у контексті ототожнення звукової сфери зі сферою активного сприйняття, навіть за умов його неочевидності: на звернене до нас ми відповідаємо всією істотою, не відповідаючи на мовлене: „Воистину, cum tacent — clamant! Ибо всегда cum tacemus - clamamaus...". У Тадеуша Кантора, для якого Театр Смерті аналог радикальної реформи сценічних дійств поставангарду, що мали за своє джерело саме життя, стаючи місцем вибуху пам'яті митця, у якого витіснений жах смерті втілюється у воскресіння мовчазних людей, вибух міг би відповідати геометричній фігурі концентричних кіл, що поширюються внаслідок розширення центральної точки - мовчання як промовистого критерію смерті.

${ }^{1}$ П. Флоренский, У водоразделов мысли, [в:] його ж, Христианство и культура, Москва-Харьков 2001, с. 33. 
У першій чверті ХХ століття, час вибухів революцій та війн, покликаних до відродження/оновлення світу, такий вибух мовчання відповідає „хаосу взрыва" 2 , де розрив/розширення центру сусідить із дисперсивністю корпускул, які зберігають сліди цілісного творіння, що спонукає їх до нескінченних спроб збирання в цілісності, де втрата форми й оформленості постає сигналом про народження нової форми, форми як хаосу.

У Театрі Смерті хаос вибуху дістає неочікуване проявлення. На зразок теорії театру смерті живого актора й реконструкції в нім унікального символу - надмаріонетки Едварда Георга Крега. За Крегом, надмаріонетка не банальна лялька, а форма зображення божества, властива єгипетському мистецтву. Надмаріонетки „настолько молчаливы, что их немота схожа со смертью"3. Вони зовсім не містять сентиментальності, емоційності, самовиражальності художника: бути великим художником - бути мертвим для емоцій. Сп'яніння/просвітління - досвід театру смерті, у якому надмаріонетка - аналог жерця, котрий володіє таємницею життя і смерті. Вона „не станет соревноваться с жизнью и скорее уж отправиться за ее пределы. Ее идеалом будет не живой человек из плоти и крови, скорее тело в состоянии транса: она станет облекаться в красоту смерти, сохраняя живой дух"“4; iï мовчання - холодний і спокійний вияв тріумфу в стані відкриття/закриття потаємного.

На противагу цій концепції Театру Смерті як сцени конденсованого мовчання утверджується Театр Жорстокості Антонена Арто, де Смерть уключена у сферу екстремального дійства й вивільнення жорстокої сили, що супроводжується війнами, страшними злочинами, які набувають особливої виразності „на фоне ужасающего восторга мифов, никогда не умирающих в сознании больших масс людей"5. Театр жорстокості у філософському сенсі - не театр побутового садизму: уживаючи слово cruauté (крюоте), режисер підкреслював його метафізичну сутність, значення „жажды жизни, космической суровости и неумолимой необходимости, [...] в гностическом смысле жизненного выхря, пожирающего мрак, в смысле той роли, за пределами неотвратимой необходимости, с которой жизнь не в силах справиться"'.

Вибух мовчання в театрі жорстокості - вихід за межі слова та його виражальних можливостей, „развитие в пространстве, дробное вибрационное

${ }^{2}$ М. Ямпольский, Форма взрыва (Письмо М. Ямпольского Комитету премии), Премия Андрея Белого, http://belyprize.ru/?pid=169 [дата доступу: 20.04.2017].

3 Э. Г. Крэг, Актер и сверхмарионетка, www.puppets.ru/upload/file/Крэг\%20Г.\%20Актер\%20и\%20сверхмарионетка.doc [дата доступу: 25.04.2017].

4 Там само.

5 А. Арто, Театр и его Двойник. Фрагменты из книги, пер. Г. В. Смирновой, „Театр” 1991, № 6, c. 125.

${ }^{6}$ Цит. за: В. Максимов, Антитеатр Антонена Арто, „Театр” 1991, № 5, с. 130. 
воздействие на наши чувства”, „создание метафизики слова, жеста и выражения, с тем чтобы оторвать их от монотонного психического бытия человека"7. Це магічний театр, який приховує в собі спокусу творення з хаосу життя у сферах космічного порядку, куди театр давно не входив: „он окончательно порывает с подчинением сознания языку, выдвигая новое и более глубокое понимание интеллектуальности, которая таится в жестах и знаках, поднятых до уровня заклинания"8.

В історії українського авангардного театру 1920-х знаку „Театр Смерті” немає: творча інтелігенція, перейнята ідеями вибуху elan vital Анрі Бергсона та динамічного еволюційного перетворення Рудольфа Штайнера, супроводжує інтенсивне переживання „смерті мистецтва”,,смерті академічного театру” справжнім вибухом інших конотацій „нового театру”: „театр колективу мистецької дії” (М. Терещенко), „театр розумного арлекіна”, „театр однієї волі”, „театр люциферичного дійства” (Л. Курбас) тощо. Парадокс: театр „на межі”/,на грані” стає театром необмежених шукань. Ще в Театральному листі (1918), викликаному дискусією (за участі Крега) про кризу театру, Лесь Курбас формулює їі як істинну проблему:

Куди іти роздвоєній душі сучасності?

Чи в незавершений понурий таємничий храм у Саїсі, де за невідслоненою завісою досі приховується нове пророцтво чи нова нерозгадана тайна, де, як смерть, вабить можливість інтуїтивної розгадки буття, де в гострих закрутах в'ються лабіринти відродженого духу середньовічного мистецтва, блідого аскетичного обличчя, складених молитовно рук, очей містично темних, осяяних новою нерелігійною ідеєю, де дух буде жестом, а жест буде духом, де в голосі почуються глибини, які порушити блюзнірською нотою було б блюзнірством?

Чи йти туди, куди тягне вся нервова істота людини, яка родилась в XIX столітті, тому столітті, що дало людству крик-музику...

Чи йти за другим імпульсом, що кинула його в кров кому рятуючи себе людськість, іти за викликаним маревом буйного, колоритного, сильного життя безповоротно все-таки минулих епох, бо сучасне життя зразків подібних дати не може...

Десь поміж цими двома полюсами блукає синтез: стиль нашого часу, основа його форм. Між переважно духовним і переважно фізичним. Між дійсністю нової нормальності нервових станів і ідеалом, змальованим фарбами минулого 9

Зразок перетворення - смерть у руках людини - подія в модальності посибілізму, приступна акторам і режисеру „з сильним творчим життям”, спрямованим на заповнення

пустого простору сцени тим, що можна виявити тільки засобами сцени. [...]. Можливо, що слів майже не буде... Можливо, що їх заступить багатство примітиву звуку.

${ }^{7}$ А. Арто, Театр и его Двойник..., с. 126.

8 Там само.

9 Л. Курбас, Театральний лист, [в:] його ж, Березіль: Із творчої спадиини, упоряд. і прим. М. Лабінського, передм. Ю. Бобошка, Київ 1988, с. 209-210. 
Можливо, що відродиться театр імпровізації. Можливо, що буде і те, і друге, і третє у різній новій диференціації театру ${ }^{10}$.

Потужний вибух життєтворчості, що структурує дискурс смерті в театрі та в теоріях Театру Смерті, зумовлює текст, де ситуація театру перестає бути реальним об'єктом зображення, де вона випадає зі сфери ілюстрації факту. Імператив переживання, покликаний деформувати реальність за принципом „,не об'єкта, а суб'єкта, захованого в об'єкті' 11 , зразком чого визнано Крик (1903) Едварда Мунка, проривається в літературу, пронизану проблемою „,театру у світі”/,світу як театру”. Як у новелі адоратора експресіонізму Миколи Хвильового „Лілюлі” (1923). Парадокс вибуху мовчання тримається тут не тільки на неочікуваному виплеску болю та фрустрації „бувших”, „білих ворон” за принципом „що в п’яного на язиці, те в тверезого на думці..."12. Це не тільки вияв бажання захиститися живим словом від тотальної влади смерті чи то в межах афекціональної (любовної) теорії мови Емануеля Сведенборга, що утверджує силою почуття реконструктивну повноту найменшого фрагмента, чи то в стилі велемовності шекспірівського Фальстафа, жарти якого - спосіб уникнути смерті, яку він так ненавидить.

Він співвідносний у Хвильового із особливим статусом театрального дійства, насамперед у межах театру-експерименту Ромена Роллана, можливості якого він пов'язував із драмою Лілюлі (Liluli, 1919). Найпростіше текстологічне зіставлення дозволяє вести мову про піднесення „вибуху інтертексту” до другого ступеня: дискурсивна рамка, окреслена паратекстом у першій публікації новели („Павлові Тичині: «Власне і це — вар'яція на темy vita nova. I тут спектакль, і тут знайомий Вам квартет: товариш Огре, горбун, Льоля і Маруся». - Присвячую"13) „обкарнана” в наступних до „Павлові Тичині”"14, відкривала сцену для інтерпретації у вимірі différance Жака Дерріда, коли відкрита сцена виявляється лише сценою, деформованою кулісами,

невидимым и неощутимым плотным полотном, которое по отношению к тем другим сторонам выполняет функцию зеркала или отражателя, а по отношению ко внешнему [...] - роль негативного проявителя, на котором надписи, производимые одновременно на других поверхностях, проявляются в перевернутом, вытянутом, зафиксированом виде ${ }^{15}$.

Ілюзія куліс від самого початку вносила деформацію в інфантильне нарцисистичне блаженство самоідентифікації в традиційний деконструктивний

10 Там само, с. 210.

11 С. Савченко, Експресіонізм у німецькій літературі, [в:] Експресіонізм та експресіоністи. Література, малярство, музика сучасної Німеччини, ред. С. Савченка, Київ 1929, с. 23.

12 М. Хвильовий, Твори: у 2-х томах, т. 1, Київ 1991, с. 376.

13 М. Хвильовий, ,Лілюлі”, „Червоний Шлях” 1923, № 6-7, с. 4.

${ }^{14}$ М. Хвильовий, Твори..., с. 377.

15 Ж. Деррида, Диссеминация, пер. Д. Кралечкина, Екатеринбург 2007, с. 384. 
спосіб: 1) через порушення спокою на дзеркальній поверхні води, і1і збурення, прорив хаосу в часову впорядкованість і послідовність, мішаниною зими й весни; 2) через збереження дзеркалом своєї обмеженої фізичної природи, що є лише сумнівним натяком на безмежність і глибину: вода, що 3 ним асоціюється, відсутня; іiі можна набрати хіба із крана. Та розлад дзеркальної інфантильності й взаємовідбиття дзеркальних поверхонь передбачають взаємонакладання віри й відчаю, „веселичності” й „,тоски”, двох „водяних” подій: діряві чоботи чужого сучасності Огре пропускають воду / „під Новий рік і Водохрещу [...] гадають про майбутнє на воді з воском"16; двох відчуттів „савоярського хлопчика” - голодної фрустрації та поетичного захоплення життям 3 його безмежністю й невідомістю. Розламана дзеркальність куліс в елімінованому реєстрі діючих осіб задана асиметрією екзальтованого представника „каесему” Марусі та трьох чужих новому часу, рештків минулого, „іскопаємих"/,трупів”17: Огре, Альоші, Льолі. Ефекту дзеркала Хвильовий досягає завдяки Зігмунду Фройду, захоплення яким письменника в опосередкований спосіб підкреслював часопис „Червоний шлях”, помістивши „, люлі” поряд із інтерпретаціями психоаналізу ${ }^{18}$. У Фройда йому відповідає „меланхолія” - той тип уяви/проекції, яка є трансформацією скорботи, і1ї загостренням, зумовленим безповоротною втратою не світу чи іншого, а втратою себе чи виявом себе як іншого, витісненого: при скорботі світ стає бідним і пустим; при меланхолії таким є власне Я $^{19}$. Постфройдівська, лаканівська філософія дзеркала констатувала тут трагедію того ідеального Я, яке завдяки „роботі печалі/скорботи ” зустрічало в дзеркалі своє справжнє бажання, що не відповідало ідеальному образу; тривога людини дзеркала - зустріч із присутністю того, що мало бути відсутнім ${ }^{20}$. У цім світлі театр Хвильового - театр, катарсистичні можливості якого співвідносні з виявленням джерела жаху „переходової доби” як постлюбовного часу викиднів неромантичної реальності більшовизму. Це театр, дзеркальний механізм якого дістав такий опис: „За проекцией образа неизменно следует проекция желания. Соответственно, существует ре-интроекция образа и ре-интроекция желания. Игра взаимоопрокидывания, игра в зеркале"21. Взаємоінверсія ідеального образу й бажання може пояснити не тільки мовчазне приниження „некрасивим

${ }^{16}$ М. Хвильовий, Твори..., с. 372.

17 Там само, с. 370.

18 Е. Берглер, Психоаналіз. Суть та значення науки проф. 3. Фрейда, „Червоний Шлях” 1923, № 6-7, с. 119-135.

19 3. Фрейд, Печаль и меланхолия, [в:] його ж, Художник и фантазирование, пер. К. Долгова, Москва 1995, с. 252-259.

20 Ж. Лакан, Тревога (Семинары. Книга X (1962/63)), пер. А. Черноглазова, Москва 2004 , c. $403-420$.

21 Ж. Лакан, Семинары. Книга 1: Работы Фрейда по технике психоанализа (1953/54), пер. М. Титовой, А. Черноглазова, Москва 1998, с. 237. 
карликом”22 „(теж) некрасивої жінки”23, але й сенс самої „vita nova” в першому варіанті паратексту новели: залишок від „Ave, vita nova! - morituri te salutant" 24 Андрія Ніковського, який пов'язував феномен нових артистичних постатей у літературі 3 „повним життям”, „першими ознаками [...] багатства", „лишку [...] розкоші, не необхідного"25: порожнеча дзеркальності стає місцем переповненості антитетичністю, симетрією екзистенційного краху та естетичної потужності.

Криве дзеркало, маркером якого була редукція посвяти, спрацьовувало вже в назві новели, яка енонсувала преконструкт на рівні залишку/рештки: він „тільки назва”, „одна назва”, назва-провокація, назва, що не відповідає сенсу того, що вона називає. Це - уламок тексту Ромена Роллана, який після вибуху цілісності взяв на себе сміливість говоріння. Можлива театральна подія, окреслена Хвильовим як пародія на Лілюлі (Liluli), — пародія пародій: як це зринає в самому тексті, це пародія не на текст Роллана, а на його сценічне втілення, пародія як спосіб реакції на чуже слово, що належить не літературі, а театру. Однак логіка пародіювання, коли ,автор вводит в чужое слово смысловую направленность, прямо противоположную чужой направленности" 26 , передбачає не просту експансію іронії. Пародійне слово - феномен революції, радикальний досвід якої співвідносний зі стиранням досі існуючого „до основ”, до точки, що є власне поворотом до точки як місця часового зсуву, замикання розриву між часами, між минулим і майбутнім, між мовчанням і мовленням, точки „еще не рожденного значения" ${ }^{27}$. У новелі Хвильового „точка” маніфестує долю театру чи, радше, факт краху академічних театрів: „[...] барахло минулого: академтеатр. Точка...”28. На території ілюзії куліс „точка” - можливий аналог топосу рецепції події, яка сигналізує про ілюзорність ейфорії, викликаної цим фактом. За суперечливою історією інсценізації драми Лілюлі Борисом Глаголіним у Харкові 4 листопада 1922 року ${ }^{29}$, кінець традиції супроводжувався не так їі смертоносними випадами проти нового театру, як хворобою міщанства самих „нових”. За цих обставин „точка” - знак у щілині між двома смертями, між двома полюсами театрального життя, відповідник смерті театральності. I то насамперед смерті театралізації смерті, що є аналогом видовищності, перформності, позбавленої

22 М. Хвильовий, Твори..., с. 377.

23 Там само, с. 375.

24 А. Ніковський, Vita поva, [в:] Українське слово. Хрестоматія української літератури і літературної критики ХХ століття: $y$ 4-х книгах, кн. 1, упоряд. В. Яременко, Київ 2001, c. 638.

25 Там само.

26 Ю. Кристева, Слово, диалог и роман, [в:] їі ж, Избранные труды: Разрушение поэтики, пер. Г. К. Кошелева, Б. П. Нарумова, Москва 2004, с. 175.

27 А. Магун, Поэтика революиионного времени: Гёльдерлин и Мандельштам, „Новое литературное обозрение" 63, 2003, с. 47.

${ }^{28}$ М. Хвильовий, Твори..., с. 358.

29 Г. Веселовська, Украӥнський театральний авангард, Київ 2010, с. 44-77. 
філософської глибини. Відтак фронтальна іронія опонентів Глаголіна, викликана оголеним прийомом „художнього терору” в агітаційно-революційній містерії, підноситься Хвильовим до другого ступеня алюзією на іншу його виставу - Собака садовника, де буквальне прочитання назви-афоризму драми Лопе де Вега Собака на сіні (El perro del hortelano, 1618) сприймається за плаский перенос у вимір площини/плакату найважливішої цінності ренесансної людини - любові, „запах життя” в якій відчувають Марусі/не-Марії. Певне лукавство в режисурі „російського Протея”, відкрите для прихильників театру-студії Курбаса, створеній як випад проти Франциска Ланга, можна зрозуміти із невідповідності самопрезентації російського актора-гастролера (,лихорадочный темп, которым пьесу заразила сама жизнь - условия моей театральной каторги”) і реальності (,со случайной труппой, собравшейся на спектакль, он пытался решить театральне задачи, требующие от актеров особой выучуки" 30 ). Хвильовий використає в окільний спосіб надійну зброю інтелектуалів: ускладнену парадоксальність. У вербальному вимірі новела містить лише натяк на події в театрі та виставу Лілюлі, лише ледь помітну вказівку на тріпотливу підготовку до спектаклю та його вдалий результат. Однак така імплікація „смерті в театрі”,,,театральної смерті” надає їй виняткової вибухової сили, розсипаючи уламки в реальному житті. Смерть стає необхідністю для живого, про що свідчить парадокс кречмерівської сферичності. Ї̈ї присутність виявляється не тільки в депресивності, яка охопила все: небеса, живі істоти, машини („Знову в порожній вулиці біжить тротуаром похилий пес. Тихо вмирає блакить... I знов на далеких пустирях тоскує трамвай"31). Справедливість відчуття присутності смерті, тут, як завжди у Хвильового, визначає найбільш тонкий ольфакторний досвід (світ пахне приреченістю, „як запах на клумбі: тютюн”32), якому відповідає сферичне пізнання, що відбувається на окраїні свідомості. ІІї прозора/туманна асоціативність збережена Хвильовим засадничо: вона інтенсифікується після повернення зі смерті в життя, що сприймається за слід палінгенесії/реінкарнації, відродження, повторного народження: їх символами в новелі $є$ „заводський квартал, що вже не мовчить - вийшов із німого мертвого кола...”, та місто/город, у центрі якого ще „Гудка не чути”з3. Гудок як сигнал про вихід із мовчання вносить в очевидне важливий деконструктивний нюанс, так що істина платоніків про повторне народження, яке супроводжується забуванням, утратою пам'яті про всі попередні життя й смерті, зазнає розхитування внаслідок подвійного доповнення. У Дерріда перший крик, вибух живого голосу як зруйноване/пі-

30 Русский Протей. Письма Б. С. Глаголина А. С. Суворину (1900-1911), Вс. Э. Мейерхольду (1909-1911), [в:] Мнемозина. Документы и факты из отечественного театра ХХ века (памяти Константина Лазаревича Рудницкого), публ., вступ. ст. В. В. Иванова, Москва 2009, с. 39.

${ }^{31}$ М. Хвильовий, Твори..., с. 366.

32 Там само, с. 357.

33 Там само. 
дірване мовчання сигналізує про народження необхідності пізнання нового, що життя пропонує в словах. Життя - лінгвістичний досвід, але такий, що виходить за межі комунікативності: Слово = Бог більше за створене буття й міститься поза буттям, воно hyperous; слово - поміж простором таємниці й простором тотожності, воно стимулює апофатичну діяльність. У цім контексті театр постає аналогом території ініціації, яка $€$ „за пределами всяких позиций”, місцем поміж місцем збереження Таємниці й долучення до неї тих, хто складає спільноту, містичну спільноту, що виливається в псевдо-містагогічну місію актора ${ }^{34}$. Друге доповнення співвідносне з природою слова гудок: воно - тільки сигнал, який не знаходить семічних еквівалентів. Тож стосовно підірваного мовчання театр покликаний виконати подвійну антитетичну функцію: визначити не тільки можливість/неможливість нового, але і його фіксації в тексті.

Унікальною точкою Театру Смерті є особлива людина - Альоша. Йому належить репліка про невідворотність власної смерті: „[...] нудно мені, Ізмайле, і скоро я умру"35. Нудьга як смертельний синдром підносить героя над враженими „розпроклятою тоскою” 36 , що відбиває ритм наближення „до гробовой доски”, асоціативним зв'язком із словом нудота. Безпристрасне тлумачення нудоти в словнику: „Стан, викликаний [...] відсутністю інтересу до довкілля. [...] Стан, що характеризується неспокоєм, тривогою, в поєднанні з сумом” / „Неприємне, млосне відчуття у шлунку й горлі, після якого часто настає блювання" 37 - увиразнюється євангелійським контекстом. Це слово на позначення стану людини Голгофи, що підкреслює Хвильовий: ,його [Альоші] очі нагадують Голгофу, коли йшов легендарний Христос на Голгофу"38. Дмитрій Мережковський тлумачить сенс такого

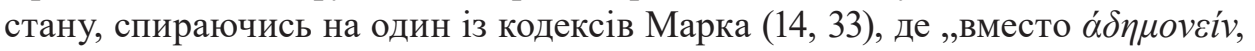

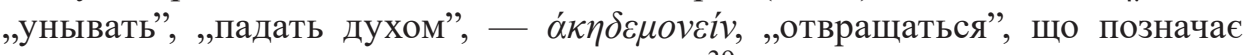
„страсть к страданию и страх страдания”" 39 , аналог агонії, яку переживає Христос, покинутий не лише Батьком, а й учнями, які не чують такого „моління про чашу”. Для Мережковського це вияв жалісної/жалюгідної міри всього людства, яке не може прокинутися від такого крику: такий сон - тожсамість агонії, ще одна агонія поряд з агонією Христа ${ }^{40}$.

В аспекті Голгофи вибухова нудьга Альоші аналогічна безмовному терпінню „некрасивої жінки”, яка після неочікуваного приниження, учи-

34 Ж. Деррида, Как избежать разговора: денегачии (Comment ne pas parler), пер. Е. Гурко [в:] його ж, Оставь это имя (Постскриптум), Как избежать розговора: денегации, ред. Е. Гурко, Минск 2001, с. 270-271.

${ }_{35}$ М. Хвильовий, Твори..., с. 378.

36 Там само, с. 372.

37 Великий тлумачний словник сучасної украӥнської мови, ред. В. Бусел, Київ 2003, с. 627.

${ }_{38}$ М. Хвильовий, Твори..., с. 360.

39 Там само, с. 641.

40 Там само, с. 642. 
неного Альошею, „мовчки відійшла, знизивши голову, як на Голгофу”41. Його вибуховий жест (плювок в обличчя), а не слово - свідчення ілюзорного істеричного повороту до архаїчного світу воївників, а не утвердження в реальності „ordre de bataille"42. Агресія не має нічого спільного 3 вітальною реальністю: в умовах іï переосмислення в іншому регістрі $\epsilon$ вона „экзистенциальным актом, связанным с воображаемым отношением"43. Вибуховий жест Альоші радше відповідає вершинній стадії переживання тривоги/скорботи, на позначення якої психоаналітики вживають слово niederkommen, у якому сенс „народжувати” співвідноситься із „,падінням, випаданням, сходженням униз", що є найпромовистішим суїцидальним синдромом. Тож суїцидальну перспективу навряд чи порушить „площадне слово 44 персонажа, яке елімінує його романтичну патетику: мат/обсценний лексикон воїна-берсеркера є таким же ілюзорним рятівником, як і жест садиста. У тексті йому відповідає три крапки, відсутність слова як можливий код неможливості/марності дискурсу, відмова від будь-якої відповідальності за себе. Крайня інаморія співвідносна з повним лібідіальним виснаженням, смертю найменших бажань. Тут немає місця для бажання втраченого іншого. Тут процес розвивається самопливом в напрямку вивільнення від самовтрати, що іiї відкриває смерть.

У фокусі Лілюлі Роллана Альоша - хрест Альтаїра та Полішинеля, прекрасного вісімнадцятирічного юнака, відомого 3 полотен італійського Ренесансу (насамперед Рафаеля й Перуджино), та горбуна-циніка, знищених ілюзією.

Але стратегія пародіювання, яка вибрана Хвильовим на рівні ефекту деформації куліс, передбачає мультиваріантне взаємопроектування дзеркальних і розбитих образів. Тож Альоша, в імені якого філософи зауважили приреченість на рух/шлях до смирення, як у випадку з персонажем Федора Достоєвського Альошею Карамазовим ${ }^{45}$, відбиває рух від говоріння до мовчання, від заклику до слухання чи окреслення власної готовності слухати (Алло!/Альо!) до раптового заперечення необхідності висловитися, заклику до тиші й мовчання (,ша!”). Така динаміка відповідає одвічному парадоксу:

Молчание торжестует в нарушении молчания - в приказе умолкнуть. Значение отвергает само то отвержение, то „ша”, которым уже (тайно) является язык, и тем самым виводит его на чистую воду. Значение слова, как мгновенный электрический импульс, пробегает через накопленное содержание с момента остановки обратно как компенсация подавленной подвижности, задержанного дыхания. Слово значит, так сказать, вопреки себе - оно действительно могила, но могила самому себе $\mathrm{e}^{46}$.

${ }^{41}$ М. Хвильовий, Твори..., с. 377.

42 Там само, с. 370.

43 Ж. Лакан, Семинары..., с. 235.

44 М. Хвильовий, Твори...

45 Див.: П. Флоренский, Имена, Москва 2007, с. 176-177.

46 А. Магун, Поэтика революиионного времени..., с. 55. 
Ще виразніше енантіодромія мовлення/мовчання виявляється на території письма.

Альоша - не письменник, а скриптор. Його історія розгортається в площині не творчої фантазії, а переписування героїчних п’єс для Льолі. Сучасники Хвильового вважали таку ситуацію за фройдівський еквівалент сексуального знесилення мужчини: він „горбун”, „некрасивий карлик, євнух, без рослини й пом'ятий'47. Письмо - один із еквівалентів фантазії коїтусу в імпотентів, а насамперед - коїтусу з матір'ю як можливого способу повернення в її лоно, гарантії здобуття в нім відчуття захищеності, яку людина втратила в реальності, що й спричинило стан фрустрації 48 .

Ж. Дерріда не без урахування фройдівського коду вбачає у волі до письма спосіб подолання хвилювання перед буттям, єдиний вихід із цього хвилювання: „Быть взволнованным, тронутым — это быть конечным: писать же значало бы хитрить с конечностью, хотеть достигнуть бытия вне сущего, бытия, которое не могло бы быть тронутым и не могло б затронуть меня"49. Але писати - значить „хотеть забыть различие; забыть письмо в присутствующем, так называемом живом и чистом слове" ${ }^{50}$. Письмо в Дерріда - pharmacon. Це судження сформувало особливий літературний досвід: за Паскалем Кіньяром, письмо у своїй амбівалентній вибуховості маркує ту несвідому силу, яка більша за самого маркувальника: „Яростная сила быка, сок в стебле цветка сильнее, чем они сами. И то, и другое можно определить французким словом virulent - ядовитьй, опасный. Словом virus обозначали и сок растений, и сперму млекопитающих, и яд, извергаемый змеями"

Репрезентація вірулентності письма в Театрі Смерті, закономірно, співвідносна із тим, хто до нього спонукає: у Хвильового Альоша пише для своєї сестри Льолі, такого ж уламка зачарованості невідомістю/неможливістю, а тому „надзвичайно наелектризованою” 52 в очікуванні прем'єри. Ïї ім'я зберігає сліди і рафаелівських „Лю”, „льольоні” Тичини, і вигаданої адресатки Курбаса „пані Ліллі”, але насамперед надмаріонетки Крега й Лілюлі (Ілюзії, Солодкої Омани) - маленької, тоненької білявки з блакитними очима, у сукні фентезі в дусі Боттічелі, сіро-блакитного кольору Роллана: „Льоля з волоссям різдвяних ляльок і з тендітним біло-рожевим обличчям. Обличчя нагадує серпанкову фату — під вінець" ${ }^{\prime 3}$. Лілюлі в Р. Роллана $є$ центром нового гнучкого театрального дійства, покликаного

${ }^{47}$ М. Хвильовий, Твори..., с. 360.

48 3. Фрейд, Истерия и страх, пер. А. Боковикова, Москва 2006, с. 219.

49 Ж. Деррида, Сила и значение, [в:] його ж, Письмо и различие, пер. Д. Кралечкина, Москва 2007, с. 24.

50 Там само.

51 П. Киньяр, Ладья Харона: роман, пер. И. Волевич, Москва 2012, с. 161.

52 М. Хвильовий, Твори..., с. 358.

53 Там само. 
до великого синтезу трагедії та сміху, реалій Першої світової війни й фантазії, вольтерівського роману й музики, симфонічних прелюдій й інтерлюдій тощо. Її світ - страждання й смерті людей, які стають високим об'єктом переживань поета; їі присуд — розп’яття того, хто відгукнувся на вимогу любові; 1іi мудрість — якнайшвидше вбивство друга, з тим щоб зберегти чисту пам'ять про нього, щоб вивести його із життя у славу, іiі музичний голос кличе до прірви. Деконструктивний маневр Хвильового відносно Лілюлі може передати судження: „Безперечно, ілюзія прекрасна річ, але - на жаль, не завше" 54 . Воно не містить ні прямого пасусу проти ілюзії, ні їі акцептації; його можна кваліфікувати як запрошення до таємничого світу ілюзій з метою непростої роботи: розрізнення варіантів ілюзії. Ілюзія, яка заповнює розломи у світі, здійснює це в парадоксальний спосіб розриву зі світом шляхом збереження зв'язку із пренатальною цілісністю: Льоля/ лялечка, „тендітна дівчинка, яка літає, як метелик”55. Ïї територія - остання лексія тексту, структурована топосом шукання води для вгамування спраги: Льоля радить Альоші дістати воду з крана. Навіть монопризматика Фройда дозволяє розгледіти тут оновлену історію народження героя мудрою жінкою й через порятунок його у воді, що аналогічне анабазису до пренатальних вод материнського лона, i через вивільнення витіснених сексуальних бажань („Цілком зрозуміла й заміна чоловічого органа об'єктами, 3 яких витікає вода: кранами, поливайками, фонтанами" ${ }^{56}$ ), через спокусу і самовбивством, і насолодою життям. Льоля/ілюзія співвідноситься із тим типом мовчання, що суттєвіше за ілюзію письма: за умови розрізнення „молчания, которое убивает”,,молчания, которое призывает” „письма вполне достаточно, чтобы убить молчание, но недостаточно, чтобы ответить на его призыв” "57. Льоля, яка впродовж усього тексту „надзвичайно наелектризована"58 в очікуванні прем'єри, дозволяє передбачити третій тип мовчання, що „замыкается в себе, окукливаясь, и в этой куколке новые истории трепещут своими крыльями"59. Вибух їі мовчання поза словесними еквівалентами, вибух-зяяння (,Льоля фаркнула"60) породжує таку ж інтерпретаційну безпорадність в озвученні коду мовчання, від якої може порятувати хіба досвід тексту-інтервалу, тексту-паузи, відповідника театру-інтеракції, „между актами», театру „антр-акта” чи „,актов интервала”61 на зразок ро-

54 Там само, с. 363.

55 Там само, с. 377.

56 3. Фройд, Вступ до психоаналізу. Лекиії з психоаналізу з новими висновками, пер. П. Таращук, Київ 1998, с. 150.

${ }^{57}$ М. Николчина, Значение и матереубийство. Традиция матерей в свете Юлии Кристевой, пер. З. Баблоян, Москва 2003, с. 158.

${ }^{58}$ М. Хвильовий, Твори..., с. 358.

59 М. Николчина, Значение и матереубийство..., с. 158

${ }^{60}$ М. Хвильовий, Твори..., с. 377.

${ }^{61}$ М. Николчина, Значение и матереубийство..., с. 157. 
ману Поміж актами (Between the Acts, 1938) Вірджинії Вулф. Він так само окутаний питаннями: у ньому замовчаний традиційний порядок говоріння чи примушене заговорити мовчання; у ньому вловлюється альтернативний, німий код чи позиціонована думка про неможливість жодного опануванням кодом; цей інтервал співвідносний з еліпсисом чи 3 метафізичним тире тощо ${ }^{62}$ Відповідник неможливості в тексті - антр-акті Хвильового - слово-сумнів ,мабуть” в останньому реченні. В ієрархії Хвильового це слово кінця/початку, безсилля/сили, невпевненості/категоричності:

Застигла тиша і скиглить

Круків примарною печаллю...

Невже не можна запалити

Тебе, заводе, хоч одчаєм ${ }^{63}$

Так Театр Смерті у версії Хвильового постає об’єктом сумнівної ідентифікації. Напевно, його можна було визнати за символ високого мистецтва чужих „перехідній добі”, які порушували плакатну ейфорію „сучасних” чи орнаментальний відчай „бувших” текстами-вибухом хаосу, у яких слово було й проривом мовчання, i його імплікацією, стимулюючи вибухонебезпечне алогічне мислення інших. Якби не емоційний залишок, нестримуваний подив від волі morituri перетворити цей театр очікування свята („,праздника”), час „праздности” в головну подію власного життя — смерть.

\section{Бібліографія}

Arto A., Teatr i ego Dvoinik. Fragmenty iz knigi, per. G. V. Smirnova, „Teatr” 1991, № 6.

Bergler E., Psyhoanaliz. Sut' ta znachinnja nauky prof. Z. Frejda, „Chervonyj Shljah” 1923, № 6-7. Velykyj tlumachnyj slovnyk suchasnoi' ukrai'ns'koi' movy, red. V. Busel, Kyi'v 2003.

Derrida Zh., Disseminatsiya, per. D. Kralechkina, Ekaterinburg 2007.

Derrida Zh., Kak izbezhat' razgovora: denegatsii (Comment ne pas parler), per. E. Gurko, [v:] yoho zh, Ostav' eto imya (Postskriptum), Kak izbezhat' rozgovora: denegatsii, per. E. Gurko, Minsk 2001.

Derrida Zh., Sila i znachenie, [v:] yoho zh, Pis'mo i razlichie, per. D. Kralechkina, Moskva 2007.

Florenskii P., Imena, Moskva 2007.

Florenskii P., U vodorazdelov mysli, [v:] yoho zh, Khristianstvo i kul'tura, Moskva-Khar'kov 2001. Freid Z., Isteriya i strakh, per. A. Bokovikova, Moskva 2006.

Freid Z., Pechal' i melankholiya, [v:] yoho zh, Khudozhnik i fantazirovanie, per. K. Dolgova, Moskva 1995.

Frojd Z., Vstup do psyhoanalizu. Lekcii' z psyhoanalizu z novymy vysnovkamy, per. P. Tarashhuk, Kyi'v 1998.

Hvyl'ovyj M., ,,Liljuli”, „Chervonyj Shljah” 1923, № 6-7.

Hvyl'ovyj M., Tvory: u 2-h tomah, t. 1, Kyi'v 1991.

Jampol'skyj M., Forma vzryva (Pys'mo M. Jampol'skogo Komytetu premyy), Premyja Andreja Belogo, http://belyprize.ru/?pid=169.

Kin'yar P., Lad'ya Kharona: roman, per. I. Volevich, Moskva 2012.

62 Див.: М. Николчина, Значение и матереубийство..., с. 155.

${ }^{63}$ М. Хвильовий, Твори..., с. 74. Курсив мій. - Г. Х. 
Kreg E. G., Akter i sverkhmarionetka, www.puppets.ru/upload/file/Крэг\%20Г.\%20Актер\%20и\%20сверхмарионетка.doc.

Kristeva Yu., Slovo, dialog i roman, [v:] yii zh, Izbrannye trudy: Razrushenie poetiki, per. G. K. Kosheleva i B. P. Narumova, Moskva 2004.

Kurbas L., Teatral'nyj lyst, [v:] yoho zh, Berezil': Iz tvorchoi'spadshhyny, uporjad. i prym. M. Labins'kogo, Kyi'v 1988.

Lakan Zh., Seminary. Kniga 1: Raboty Freida po tekhnike psikhoanaliza (1953/54), per. M. Titovoi, A. Chernoglazova, Moskva 1998.

Lakan Zh., Trevoga (Seminary. Kniga Kh (1962/63), per. A. Chernoglazova, Moskva 2004.

Magun A., Poetika revolyutsionnogo vremeni: Gel'derlin i Mandel'shtam, „Novoe literaturnoe obozrenie" 63, 2003.

Maksimov V., Antiteatr Antonena Arto, „Teatr” 5, 1991.

Merezhkovskii D., Iisus Neizvestnyi, Khar'kov-Moskva 2000.

Nikolchina M., Znachenie i matereubiistvo. Traditsiya materei v svete Yulii Kristevoi, per. Z. Babloyan, Moskva 2003.

Nikovs'kyj A., Vita nova, [v:] Ukrai'ns'ke slovo. Hrestomatija ukrai'ns'koi' literatury i literaturnoi' krytyky HH stolittja: U 4-h knygah, kn. 1, uporjad. V. Jaremenko, Kyi'v 2001.

Russkii Protei. Pis'ma B. S. Glagolina A. S. Suvorinu (1900-1911), Vs. E. Meierkhol'du (1909-1911), [v:] Mnemozina. Dokumenty i fakty iz otechestvennogo teatra XX veka (pamyati Konstantina Lazarevicha Rudnitskogo, publ., vstup. st. V. V. Ivanova, Moskva 2009.

Savchenko S., Ekspresionizm u nimec'kij literaturi, [v:] Ekspresionizm ta ekspresionisty. Literatura, maljarstvo, muzyka suchasnoi' Nimechchyny, per. S. Savchenka, Kyi'v 1929.

Veselovs'ka G., Ukrai'ns'kyj teatral'nyj avangard, Kyi'v 2010.

\section{Mykola Khvylovy: \\ The silence explosion in the Death Theatre}

\section{Summary}

The article deals with the Death Theatre in Mykola Khvylovy's works. The author of the article claims that Death Theatre is the attribute of intermittency, the transition era between the dying/passing and the one who has not been born yet. It shows its atopic/marginal status employing destroying silence, the traditional death attribute. As the analog of the "explosion chaos", it implies the destruction of clear forms up ,to the point"/ ,to the bottom" and their infinite deconstructive formation either according to the law of anagramming, or the law of reduction and ellipsis, interval and three dots as well. The gap and emptiness in the text are subject to the effect of the theatre wings deformation, the irresistible mirror/illusory of man existing in reality. This is accompanied by his balancing between the doomed melancholic and euphoria of the one after touching the secrets of creating the new and the paradox of silent, triumphant assertion in its destruction. Liluli (1923), Mykola Khvylovy's novella, a unique master of life and text, has become the basis for such judgments.

Keywords: Death Theatre, theater-interaction, différance, remnant/misbirth, "explosion chaos" 


\section{Микола Хвылевый: \\ взрыв молчания в Театре Смерти}

Резюме

Театр Смерти - атрибут междувременья, переходной эпохи, ставшей соприкосновением умирающего/отходившего и еще не родившегося, демонстрирует свой атопичный/ маргинальный статус путем разрушения традиционного атрибута смерти - молчания. Аналог „хаоса взрыва”, оно предполагает деструкцию четких форм „до точки”/,до основания" и их бесконечное деконструктивное становление по закону не только анаграммирования, но и редукции и эллипсиса, интервала и многоточия. Зияние и пустота в тексте подчинены эффекту деформации кулис в театре, непреодолимой зеркальности/иллюзорности существования человека в реальности, сопровождающееся его балансированием между обреченностью меланхолика и эйфорией прикоснувшегося к тайнам создания нового и к парадоксу триумфального утверждения молчания в его разрушении. Основания для таких суждений дала новелла „Лилюли” (1923) уникального мастера жизни и текста Миколы Хвылевого.

Ключевые слава: Театр Смерти/театр-интеракция, différance, остаток/выкидыш, „хаос взрыва" 